\title{
Effect of Prilled Fat and Yeast Supplementation on Milk Production, Fatty Acid Profile and Economics of Feeding in Murrah Buffaloes (Bubalus bubalis)
}

\author{
H.M. Ajithakumar*, Mahendra Singh, Shikha Sharma, Meeti Punitha, \\ Sikandar Sabab Khan and Brijesh Patel
}

\author{
Dairy Cattle Physiology Division, National Dairy Research Institute, Karnal-132001, \\ Haryana, India \\ *Corresponding author
}

\begin{abstract}
A B S T R A C T
The combined effects of prilled fat and yeast culture (YC) mixture supplementation were investigated on the production performance and economics in 18 early lactating Murrah

Keywords

Prilled fat.

Saccharomyces

cerevisiae.

Fatty acid profile.

Murrah buffaloes.

Economics of

feeding.

Article Info

Accepted:

17 September 2017

Available Online:

buffaloes. Buffaloes were divided into two groups as control group (CON group) and supplemented group (SG). CON group was fed wheat straw, maize fodder and concentrate mixture, while SG was supplemented additionally with $100 \mathrm{~g}$ prilled fat and $25 \mathrm{~g}$ Saccharomyces cerevisiae (SC)/day from -21day prepartum to 90 days postpartum. The effect of feeding on persistence of milk production was monitored up to day 120 of lactation. Milk yield was increased $(\mathrm{p}<0.01)$ by $18.94 \%$ in $\mathrm{SG}$ than the control group (11.93 vs. $10.86 \mathrm{~kg} / \mathrm{d})$. However protein, solid-not fat (SNF) and lactose contents were not influenced. Milk fat yield increased $(\mathrm{p}<0.01)$ by $6.16 \%$ in SG than the CON. Body weights, body condition score and DMI were improved $(\mathrm{p}<0.01)$ and Somatic cell count (SCC) was decreased $(\mathrm{p}<0.05)$ in $\mathrm{SG}$ as compared to CON group. The feeding supplement produced noticeable changes in the fatty acid profile in milk fat. Saturated fatty acids (SFA) decreased by $12.18 \%$ and unsaturated fatty acids (USFA) increased ( $<<0.01$ ) by $30.14 \%$ in the SG buffaloes. However withdrawal of feeding declined milk production $(\mathrm{p}<0.01)$. The lowered ratio of SFA: USFA indicated beneficial effects of feeding on fatty acid profile of milk for human consumption. It was concluded that prilled fat and $\mathrm{S}$. cerevisiae feeding effect was galactopoietics in nature by increasing milk yield and fat. The feeding generated an additional income of 117 INR/animal/day.
\end{abstract}

\section{Introduction}

Yeast and yeast products have been widely used to manipulate rumen fermentation and improve production performance of animals. Similarly prilled fat which is inert to rumen environment also improves the milk productivity of animals. However response on milk production depends upon diet composition, forage to concentrate ratio, type of forage, yeast or prilled fat dose, feeding strategy and stage of lactation (Dann et al.,
2000). During early lactation, the energy requirements for maintenance and milk production exceed the amount of energy obtained from dietary sources (Tyagi et al., 2010). Thus, high energy requirement at the onset of lactation results in a negative energy balance (NEB) that begins a few days prepartum and extends few weeks postpartum (Tyagi et al., 2010: Remppis et al., 2011). The NEB adversely affects postpartum health 
and overall loss in milk yield of animals (Reist et al., 2002). Bypass fat supplementation enhanced the energy intake in early lactation animals and reduces the deleterious effect of acute NEB (Tyagi et al., 2010: Ganjkhanlou et al., 2009). In some studies, yeast cultures feeding have improved dry matter intake, milk yield, and milk composition (Robinson et al., 1999 Williams et al., 1991)' whilst few studies have found no significant impact (Harrison et al., 1998: Henics et al., 1992: Schingoethe et al., 2004).

Yeast culture used as a dietary supplement for dairy cattle improve rumen function, which in turn improve milk production and feed efficiency, by stimulating selective growth of rumen bacteria species (Harrison et al., 1998). Feeding of rumen protected fat and protein to lactating cows and buffaloes increased milk yield and milk composition (Tyagi et al., 2010; Chen et al., 2002; Garg et al., 2003; White et al., 2004). In recent years consumers have become increasingly aware of the potential health benefits from consuming dairy products rich in polyunsaturated fatty acids (PUFA), particularly those in the n-3 (omega-3) fatty acid (FA) group and the conjugated linoleic acid (CLA) isomer cis-9 trans-11 C18:2 (Ruminic acid, RA) (Jensen $e t$ al., 1995).

Therefore, when devising nutritional management strategies for the early lactation elite dairy cows it is important to measure the FA profile of the milk produced. Several factors are known to influence the FA composition of bovine milk including diet (Kelly et al., 1998), rumen function (Dewhurst et al., 2006), stage of lactation and body tissue mobilization (Garnsworthy et al., 2006). The effect of prilled fat and $S$. cerevisiae feeding on milk production has been reported in isolation and the combined effect of supplementation has not been investigated. Therefore, present study was conducted to investigate the effect of $S$. cerevisiae and prilled fat feeding concurrently on milk production, milk composition fatty acid profile and economics of feeding in Murrah buffaloes.

\section{Materials and Methods}

\section{Selection of animals and treatment}

The experiment was conducted on Murrah buffaloes in field condition of Karnal district located at $29 \circ 4220 \mathrm{~N}$ and $76 \circ 5852.5 \mathrm{E}$ at an altitude of $228 \mathrm{~m}$ amsl. In summer (September-December) the daily minimum and maximum temperature averaged $15{ }^{\circ} \mathrm{C}$ and $39.5{ }^{\circ} \mathrm{C}$, respectively. Murrah buffaloes (18), in 2nd parity were divided into two groups of 9 each based on expected date of parturition (21days). CON group buffaloes were offered green fodder (maize), wheat straw and concentrate mixture $(45: 35: 10)$ at 10:00 and 19:00 hr. daily. The SG buffaloes were fed diet as in CON plus 100 and $25 \mathrm{~g} / \mathrm{d}$ of prilled fat and Saccharomyces cerevisiae (SC) from -21 days of parturition to 90 days postpartum. The effect of withdrawal of feeding on persistency of milk production was recorded for 30 days. DM content of fodder and left over residue was recorded to calculate daily DMI. Concentrate mixture contained \% maize, 33; wheat bran, 20; rice polish, 10; mustard cake, 12; barley grain, 22; mineral mixture, 02 ; and common salt, 01 .

Fresh and clean water was provided free choice to each buffalo four times a day. Buffaloes were hand milked twice a day and the yield was recorded. Milk samples were collected at weekly interval from each buffalo and pooled in proportion to the milk yield. Body condition score was recorded at the fortnightly intervals (Ferguson et al., 1994). The per $\mathrm{kg}$ cost of green fodder, wheat straw and concentrate was 2.5, 4 and 17 INR respectively. 


\section{Analysis of feed and milk sample}

The chemical composition of feeds and fodder offered during the trial period was carried as per AOAC (2005). Neutral detergent fibre (NDF), acid detergent fibre (ADF) and cellulose was determined as per Van Soest (1991) (Table 1). The fatty acid analysis of feed samples viz., green maize forage, wheat straw, concentrate was done by saponification method (Gulati et al., 2003) (Table 2). Milk samples analyzed for fat, protein, lactose and solid-not fat (SNF), using pre calibrated Milk Analyzer (lactoscan). Milk yield was converted in energy corrected milk (ECM) applying the equation proposed by Sjaunja et al., (1990). Fatty acids in isolated fat samples were re-esterified to their methyl esters by a methanolic solution of potassium hydroxide. The analysis of milk and feed was carried out on gas liquid chromatography (GLC) fitted with Flame ionization detector and 50m capillary column. Identification of peaks was recorded through retention time of the reference standards (Supelco, Bellefonte PA, and USA).

\section{Results and Discussion}

\section{Body weight, DMI and milk composition}

Metabolic body weight of buffaloes was similar in both the groups at the beginning of experiment (Table 3) however, metabolic weight increased $(\mathrm{P}<0.05)$ after the experiment in $\mathrm{SG}$ buffaloes (134.33 kg). Initial BCS was non- significant between the groups however, BCS was more $(\mathrm{p}<0.01)$ in SG over the CON (3.92 vs. 3.28) after the experiment. DMI was higher $(\mathrm{p}<0.05)$ in $\mathrm{SG}$ group in comparison to CON. Milk yields increased @ 18.94\% in the SG buffaloes over the CON. The fat corrected milk yield (FCM) and total solid were also higher $(\mathrm{p}<0.01$; $\mathrm{p}<0.05)$ in $\mathrm{SG}$ buffaloes. Milk yield though declined after withdrawal of feeding but was still high $(\mathrm{p}<0.05)$ in SG $(14.44 \%)$ in comparison to CON buffaloes. Milk fat was more by $6.16 \%(\mathrm{p}<0.01)$ in $\mathrm{SG}$ buffaloes, however solid not fat, protein, lactose and ECM were not influenced by supplementation (Table 4). There was significant reduction in somatic cell count $(\mathrm{p}<0.05)$ of milk in $\mathrm{SG}$ than the control group; the respective values were 240.30 vs. $293.60 \quad\left(\times 10^{3}\right) \quad$ cells $/ m l$ (Figure 1).

\section{Fatty acid profile}

Milk fat of SG buffaloes exhibited higher myristoleic acid, palmitoleic acid, elaidic acid, oleic acid, linoleic acid, linolenic acid and arachidic acid content as compared to CON buffaloes (Table 5). Total USFA contents were lower $30.95 \mathrm{~g} / 100 \mathrm{~g}$ total FA in CON group as compared to $40.62 \mathrm{~g} / 100 \mathrm{~g}$ total FA in SG buffaloes, showing an increase of $31.24 \%$. SFA contents was higher $(65.35 \mathrm{~g} / 100 \mathrm{~g}$ total FA) in milk of CON in comparison to SG buffalo milk $(56.97 \mathrm{~g} / 100 \mathrm{~g}$ total FA). SFA contents were decreased by $12.18 \%$ in milk of SG over that of CON. However, total LCFA content was higher in SG buffaloes $(\mathrm{p}<0.01)$ as compared to CON. Supplementation increased monounsaturated fatty acid and polyunsaturated fatty acids content $(p<0.01)$ by 26 and $39.30 \%$ respectively in SG than the CON buffaloes (Table 5). The SFA: USFA ratio in CON and SG was 2.11:1 and 1.41:1 respectively. Prilled fat and S. cerevisiae feeding incurred extra cost of av. INR 17.8/day/animal during the experimental period. The increased milk yield and fat of milk generated additional income of INR 10,320 and INR. 117/day/animal $(\mathrm{P}<0.05)$ and was highly economical (Table $6)$.

Yeast culture provides soluble growth factors that stimulate growth of cellulolytic bacteria and cellulose digestion (Callaway et al., 1997). The significant increases in milk production associated with yeast supplementation or prilled fat have previously 
been reported in dairy cows (Bruno et al., 2009: Rajesh et al., 2014). Milk yield increased by $6.03 \%$ in prilled fat supplemented cows (Rajesh et al., 2014), while Increase in milk yield due to yeast culture feeding usually range between 1 and 2 $\mathrm{kg} / \mathrm{d}$ (Robinson et al., 1999). Microbial additives such as yeast cultures had the greatest positive effect on cows in early lactation, increasing milk yield over that of control cows (Kellems et al., 1990). S. cerevisiae supplementation increased organic matter digestibility thus allowing higher energy availability for milk yield and reduced fat mobilization in buffalo (Campanile et al., 2008). Prilled fat feeding during periparturient period and early lactation increased milk yield and milk fat contents in cows (Yadav et al., 2015) and Murrah buffaloes (Shikha et al., 2016) However, some researchers (Arambel et al., 1990) Robinson et al., 1999: Bagheri et al., 2009) reported no beneficial effects of yeast feeding on milk production performance. The increase in fat percentage in the SG group was due to more availability of FAs in blood and their incorporation into milk fat in mammary gland (Shelke et al., 2012). The increased milk yield in SG buffaloes after withdrawal of feeding in accordance with earlier findings that protected fat not only increase milk yield but its effects persist even after the supplement is withdrawn in goats and cows (Tyagi et al., $2010)$. The higher $(p<0.05)$ milk production and peak yields in SG was attributed to more energy content of diet (Tyagi et al., 2010: Shikha et al., 2016). The non-significant effect on SNF, protein and lactose is an evident of this fast. Similarly the enhancement in fat yield was also observed by researches (Moallem et al., 2012 Putnam et al., 1997). Arambel and Kent, (1990) attributed ADF in the ration while maintained milk fat synthesis. Similarly some studies have shown that yeast culture had no beneficial effect on milk composition of dairy cows (Arambel and Kent, 1990; Bagheri et al., 2009; Soder et al., 1999; Swartz et al., 1994), but in lactating goats fed live yeast, a reduction in milk fat (Stella et al., 2007) or increase (Giger-Reverdin et al., 1996) have observed. However combined effect of both prilled fat and S. cerevisiae may augment the milk yield and fat than those of individual supplementation (Robinson et al., 1999: Rajesh et al., 2014). The decline of milk SCC indicated improved health status of udder (Sretenovic et al., 2008; Stein et al., 2006) and immune status of the yeast-supplemented cows due to increase in $\operatorname{IgA}$ and secretory components of immunoglobulin's (Bakr et al., 2015).

Fig.1 Average milk SCC in control and supplemental group buffaloes

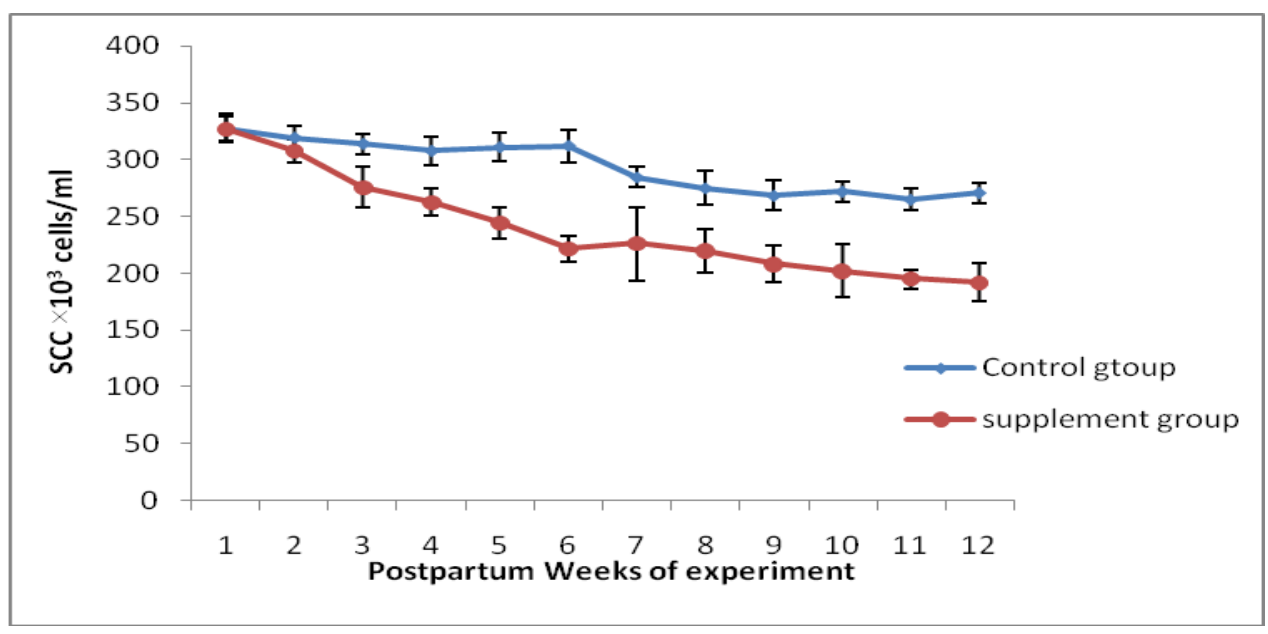


Int.J.Curr.Microbiol.App.Sci (2017) 6(10): 1757-1767

Table.1 Chemical composition of feed offered during experiment (\% DM basis)

\begin{tabular}{llll}
\hline parameters & Maize fodder & Wheat straw & concentrate mixture \\
\hline Dry matter & 18.72 & 91.2 & 93.67 \\
Organic matter & 90.93 & 92.58 & 92.25 \\
Crude protein & 9.68 & 4.11 & 23.25 \\
Ether extract & 3.02 & 2.11 & 4.67 \\
Neutral detergent fiber & 54.48 & 75.9 & 36.22 \\
Acid detergent fiber & 34.05 & 52.35 & 14.16 \\
Ash & 12.31 & 9.42 & 7.75 \\
Hemicellulose & 19.21 & 32.11 & 18.78 \\
Calcium & 1.34 & 0.17 & 1.39 \\
Phosphorus & 0.61 & 0.02 & 0.63 \\
\hline
\end{tabular}

Table.2 Fatty acid profile (g/100 g total fatty acids) of feeding ingredients

\begin{tabular}{llll}
\hline & Maize fodder & Wheat straw & Concentrate mixture \\
\hline Caprylic acid (C8:0) & 0.72 & ND & 0.66 \\
Capric acid (C10:0) & 0.86 & 0.66 & ND \\
Lauric acid (C12:0) & 3.21 & 0.86 & 2.26 \\
Myristic acid (C14:0) & 2.21 & 3.24 & 1.26 \\
Myristoleic acid (C14:1) & 0.97 & ND & ND \\
Palmitic acid (C16:0) & 23.26 & 21.34 & 15.68 \\
Palmitoleic acid (C16:1) & 2.14 & 0.32 & 0.53 \\
Margaric acid (C17:0) & ND & 4.5 & 1.33 \\
Stearic acid (C18:0) & 2.91 & 45.32 & 33.65 \\
Elaidic acid (C18:1t9) & 4.88 & ND & 3.42 \\
Oleic acid (C18:1c9) & 3.38 & 17.32 & 21.34 \\
Linoleic acid (C18:2) & 19.39 & ND & 2.83 \\
Linolenic acid (C18:3) & 31.36 & ND & 14.54 \\
Arachidic acid (C20:0) & 0.62 & 2.53 & 0.46 \\
Total fatty acid & 95.91 & 96.09 & 97.96 \\
\hline
\end{tabular}

ND: not detected

Table.3 Body weight, BCS and DMI in control and supplemented Murrah buffaloes

\begin{tabular}{lllllll}
\hline stage & \multicolumn{2}{l}{ Body weight $(\mathrm{kg})$} & \multicolumn{2}{l}{ Body condition score } & \multicolumn{2}{l}{ Dry matter intake $(\mathrm{kg})$} \\
\hline & CON & SG & CON & SG & CON & SG \\
\hline Prepartum & $646 \pm 16.97$ & $645 \pm 19.65$ & $3.35 \pm 0.14$ & $3.42 \pm 0.17$ & $16.53 \pm 0.04$ & $16.53 \pm 0.07$ \\
At parturition & $596^{\mathrm{a}} \pm 18.14$ & $608^{\mathrm{b}} \pm 18.31$ & $2.87^{\mathrm{a}} \pm 0.15$ & $2.92^{\mathrm{b}} \pm 0.18$ & $15.89^{\mathrm{a}} \pm 0.16$ & $16.25^{\mathrm{b}} \pm 0.1$ \\
Postpartum & $606^{\mathrm{a}} \pm 20.97$ & $652^{\mathrm{b}} \pm 20.35$ & $3.28^{\mathrm{a}} \pm 0.1$ & $3.92^{\mathrm{b}} \pm 0.01$ & $16.3^{\mathrm{a}} \pm 0.15$ & $17.38^{\mathrm{b}} \pm 0.1$ \\
\hline
\end{tabular}

Values bearing different superscript $a, b$ differ in a row $(\mathrm{P}<0.05)$ 
Table.4 Average milk yield and composition changes in control and supplemented group Murrah buffaloes

\begin{tabular}{llll}
\hline PARAMETER & Control group & supplement group & P value \\
\hline Milk yield (kg) during experiment (90 days) & $10.03^{\mathrm{a}} \pm 0.17$ & $11.93^{\mathrm{b}} \pm 0.18$ & 0.012 \\
Milk yield after withdrawal of feed (30 days) & $7.27^{\mathrm{a}} \pm 0.64$ & $8.32^{\mathrm{b}} \pm 0.32$ & 0.013 \\
$\quad$ & & \\
Milk composition & $7.79^{\mathrm{a}} \pm 0.05$ & $8.27^{\mathrm{b}} \pm 0.06$ & 0.013 \\
Fat, \% & $9.29 \pm 0.01$ & $9.28 \pm 0.01$ & 0.362 \\
Solid not- fat, \% & $3.45 \pm 0.01$ & $3.44 \pm 0.01$ & 0.567 \\
Protein, \% & $5.51 \pm 0.01$ & $5.49 \pm 0.01$ & 0.723 \\
Lactose, \% & $17.08^{\mathrm{a}} \pm 0.5$ & $17.55^{\mathrm{b}} \pm 0.06$ & 0.023 \\
Total solids, \% & $12.1^{\mathrm{a}} \pm 0.21$ & $15.09^{\mathrm{b}} \pm 0.27$ & 0.013 \\
6\% FCM/kg & $12.63^{\mathrm{a}} \pm 0.15$ & $14.96^{\mathrm{b}} \pm 0.23$ & 0.016 \\
ECM/kg & $1.67^{\mathrm{a}} \pm 0.03$ & $1.44^{\mathrm{b}} \pm 0.02$ & 0.01 \\
DMI kg/milk yield kg & $1.39^{\mathrm{a}} \pm 0.02$ & $1.47^{\mathrm{b}} \pm 0.02$ & 0.011 \\
DMI/FCM & $0.61^{\mathrm{a}} \pm 0.01$ & $0.71^{\mathrm{b}} \pm 0.01$ & 0.016 \\
Feed efficiency (milk yield/DMI) &
\end{tabular}

Values bearing different superscript $a, b$ differ in a row $(\mathrm{P}<0.05)$

Table.5 Average total Fatty acid profile of milk in control and supplemented group buffaloes

\begin{tabular}{llll}
\hline Fatty acids(g/100g Total fatty acids) & Control group & Supplement group & P value \\
\hline Caprylic acid (C:8) & $0.88 \pm 0.005$ & $0.83 \pm 0.003$ & 0.017 \\
Capric acid(C:10) & $3.55^{\mathrm{a}} \pm 0.02$ & $2.43^{\mathrm{b}} \pm 0.03$ & 0.035 \\
Lauric acid(C:12) & $3.82 \pm 0.01$ & $3.22 \pm 0.02$ & 0.765 \\
Myristic acid(C:14) & $11.28^{\mathrm{a}} \pm 0.03$ & $8.15^{\mathrm{b}} \pm 0.18$ & 0.014 \\
Myristoleic acid ((C:14:1) & $0.91^{\mathrm{a}} \pm 0.01$ & $2.50^{\mathrm{b}} \pm 0.05$ & 0.034 \\
Palmitic acid(C16) & $25.09^{\mathrm{a}} \pm 0.13$ & $23.09^{\mathrm{b}} \pm 0.01$ & 0.042 \\
Palmitioleic acid(C:16:1) & $1.65^{\mathrm{a}} \pm 0.07$ & $2.51^{\mathrm{b}} \pm 0.01$ & 0.051 \\
Margaric acid(C:17) & $0.63 \pm 0.01$ & $0.37 \pm 0.005$ & 0.543 \\
Stearic acid(C:18) & $20.13 \pm 0.16$ & $18.88 \pm 0.22$ & 0.0982 \\
Elaidic acid(C:18:1t9) & $2.34^{\mathrm{a}} \pm 0.001$ & $3.29^{\mathrm{b}} \pm 0.01$ & 0.014 \\
Oliec acid(C-18:1c9) & $23.87^{\mathrm{a}} \pm 0.11$ & $28.89^{\mathrm{b}} \pm 0.24$ & 0.039 \\
Linoleic acid(C-18:2) & $1.93^{\mathrm{a}} \pm 0.02$ & $2.87^{\mathrm{b}} \pm 0.02$ & 0.014 \\
Lenolenic acid(C-18:3) & $0.73 \pm 0.001$ & $0.87 \pm 0.01$ & 0.675 \\
Arachidic acid(C-20:0) & $0.47^{\mathrm{a}} \pm 0.01$ & $0.69^{\mathrm{b}} \pm 0.004$ & $<0.001$ \\
Total saturated fatty acids & $65.35^{\mathrm{a}} \pm 2.54$ & $56.97^{\mathrm{b}} \pm 2.01$ & $<0.001$ \\
Total unsaturated fatty acids & $30.95^{\mathrm{a}} \pm 1.36$ & $40.62^{\mathrm{b}} \pm 1.13$ & $<0.001$ \\
Monounsaturated fatty acids & $27.77^{\mathrm{a}} \pm 1.54$ & $35.19^{\mathrm{b}} \pm 1.21$ & $<0.001$ \\
Polyunsaturated fatty acids & $3.181^{\mathrm{a}} \pm 0.43$ & $4.43^{\mathrm{b}} \pm 0.32$ & $<0.001$ \\
\hline
\end{tabular}

Values bearing different superscript $a, b$ differ in a row $(\mathrm{P}<0.05)$

Table.6 Economics of prilled fat and S. cerevisiae feeding in the diet of lactating Murrah buffaloes

\begin{tabular}{clll}
\hline & Particulars & Control group & Supplement group \\
\hline 1 & Total feed cost (INR/animal/day) & 189 & 191 \\
2 & Cost of prilled fat and SC (INR/animal/day) & - & 17.875 \\
3 & Total expenses (INR/animal/day) & 189 & 208.875 \\
4 & Total Expenses for nine animals (INR) & 1701 & 1879.875 \\
5 & Total expense for 90days experiment & 153090 & 169188.75 \\
6 & Average daily FCM (kg/animal) & 12.1 & 15.09 \\
7 & Daily income on milk sale (INR/animal) & $544.5^{\mathrm{a}}$ & $679.05^{\mathrm{b}}$ \\
8 & Total income during experiment (INR/animal) & 4900.5 & 6111.45 \\
9 & Total income (INR) during experiment & $441045^{\mathrm{a}}$ & $550030.5^{\mathrm{b}}$ \\
10 & Net profit during experiment (9-5) (INR) & $287955^{\mathrm{a}}$ & $380841.75^{\mathrm{b}}$ \\
\hline
\end{tabular}

Values bearing different superscript $\mathrm{a}, \mathrm{b}$ differ in a row $(\mathrm{P}<0.05)$ 
The increased dry matter intake led to more feed efficiency per $\mathrm{kg}$ of milk produced (Schingoethe et al., 2004) contrary to this some studies have found no effect on dry matter intake (Schingoethe et al., 2004: Arambel and Kent, 1990 Solomon et al., 2000) or on feed efficiency (Schingoethe et al., 2004). Yeast cultures in diets of lactating cows increased total concentrations of cellulolytic bacteria in the rumen (Harrison et al., 1998). It was been found that is DMI not influenced by bypass fat supplementation in cows and buffaloes (Tyagi et al., 2010 Rajesh et al., 2014). The increased BCS and body weight probably suggest decreased body fat mobilization due to improved energy balance in prilled fat fed buffaloes Shikha (et al., 2016). However, such effect is not evident with yeast culture supplementation (Schingoethe et al., 2004: Bruno et al., 2009: Bagheri et al., 2009: Swartz et al., 1994) (Table 5).

The effects of fat supplementation on milk fat and fatty acids composition are influenced by the type and amount of dietary fat and its degree of inertness in the rumen (Ashes et al., 1999). Thus increase in milk fat content in SG could be distributed to availability of more FA (SFA and USFA) for absorption in intestine and their incorporation in milk fat by mammary gland ${ }^{32}$. The high proportions of C18:2 and cis9 in milk of SG $(p<0.05)$ corroborate the previous work reports ${ }^{43-44}$. Thus feeding of prilled fat reduced $\mathrm{C} 14$ to C16 fatty acids in milk Dhiman et al., 1999: Chichlowski et al., 2005: Delbecchi et al., 2001). The change of milk fatty acid profile would improve the quality of milk and could be beneficial to human health (Kennelly, 1997). Though use of supplemental fats increase milk fat content and yields but often decrease milk protein percentage (Lohrenz et al., 2010). The decline in SFA concentration $(12.18 \%)$ and increase in USFA (31.24\%) suggest advantages of its feeding. USFA play a vital role in prevention and treatment of cardiovascular diseases (Nordoy et al., 2001 Williams, 2001). Protected USFA escape the rumen, an absorbed from the small intestine, and incorporated into the milk fat (Staples and Cullens, 2005). However, withdrawal of prilled fat and S. cerevisiae feeding changed the proportional and incorporation of SFA and USFA into the milk fat (Sampelayo et al., 2004).

The feeding of prilled fat and yeast culture increased daily income by 117 INR/day/buffalo in this study and was highly profitable for dairy farmers. The result of the study corroborate the income generation of 114.45 INR/day/animal in buffaloes fed with prilled fat with sweetner and toxin binder (Shabab Khan et al., 2016). Feeding of the indigenously prepared bypass fat generated lower additional profit of Rs. 34.50/cow/day (Naik et al., 2009) and Rs. 39.66/buffalo/day (Parnerkar et al., 2011). However, feeding of yeast culture alone induces only INR 12.96/buffaloes/day (Srinivas et al., 2011). The present study suggests that there was no beneficial effect of supplementing the yeast culture with prilled fat as increases in the milk yield was due to prilled fat.

It was concluded that feeding of prilled fat results in higher milk yield and fat content and did not affect protein, lactose, SNF contents of milk. However increased unsaturated fatty acid contents and lowered saturated content of milk suggest that this milk was good enough for human consumption. The increase in BCS, body weight, lower SCC and more profitability by INR 117/day/animal indicate its important role in sustaining the rural livelihood in the near future.

\section{Acknowledgments}

We are thankful to the Director, National Dairy Research Institute, Karnal for providing necessary facilities to conduct the study. The 
authors also acknowledge the grant received from the BRNS in the project no. 2013/35/48BRNS with RATC Mumbai.

\section{References}

AOAC, 2005. Official Methods of Analysis, 18th ed. Association of Official Analytical Chemist, Washington, DC, USA.

Arambel, M.J., Kent, B.A., 1990. Effect of yeast culture on nutrient digestibility and milk yield response in early- to mid-lactation dairy cows, J Dairy Sci, 73, 1560-1563.

Ashes, J.R., Gulati, S.K., Scott, T.W., 1997. Potential to alter the content and composition of milk fat through nutrition. Presented at the American Dairy Science Meeting, J Dairy Sci, 80, 2204-2212

Bagheri, M., Ghorbani, G.R., Rahmani, H.R., Khorvash, M., Nili, N., Südekum, K.H., 2009. Effect of live yeast and mannanoligosaccharides on performance of early-lactation Holstein dairy cows, Asian-Aust J Anim Sci, 22, 812-818.

Bakr, H.A., Hassan, M.S., Giadinis, N.D., Panousis, N., Ostojić Andrić, D., Abd El-Tawab, M.M., Bojkovski, J., 2015. Effect of Saccharomyces cerevisiae supplementation on health and performance of dairy cows during transition and early lactation period, Biotech Animal Husbandry, 31 (3), 349364.

Bruno, R.G.S., Rutigliano, H.M., Cerri, R.L., Robinson, P.H., Santos, J.E.P., 2009. Effect of feeding Saccharomyces cerevisiae on performance of dairy cows during summer heat stress, Anim Feed Sci Technol, 150, 175-186.

Callaway, E.S., Martin, S.A., 1997. Effects of a Saccharomyces cerevisiae culture on ruminal bacteria that utilize lactate and digest cellulose, J Dairy Sci, 80, 2035-
2044.

Campanile, G., Zicarelli, F., Vecchio, D., Pacelli, C., Neglia, G., Balestrieri, A., Di Palo, R., Infascelli, F., 2008. Effects of Saccharomyces cerevisiae on in vivo organic matter digestibility and milk yield in buffalo cows, Livest Sci, 114, 358-361.

Chen, K.J., Jan, D.F., Chiou, P.W.S., Yang, D.W., 2002. Effects of dietary heat extruded soybean meal and protected fat supplement on the production, blood and ruminal characteristics of Holstein cows, Asian-Aust. J Anim Sci, 15, 821827.

Chichlowski, M.W., Schroeder, J.W., Park, C.S., Keller, W.L., Schimek, D.E., 2005. Altering the fatty acids in milk fat by including canola seed in dairy cattle diets, J Dairy Sci, 88, 3084-3094.

Dann, H.M., Drackley, J.K., McCoy, G.C., Hutjens, M.F., 2000. Garrett, J.E., Effects of yeast culture (Saccharomyces cerevisiae) on prepartum intake and postpartum intake and milk production of Jersey cows, J Dairy Sci, 83, 123127.

Delbecchi, L., Ahnadi, C.E., Kennelly, J.J., Lacasse, P., 2001. Milk fatty acid composition and mammary lipid metabolism in Holstein cows fed protected or unprotected canola seeds, $J$ Dairy Sci, 84, 1375-1381.

Dewhurst, R.J., Shingfield, K.J., Lee, M.R.F., Scollan, N.D., 2006. Increasing the Concentrations of Beneficial Polyunsaturated Fatty Acids in Milk Produced by Dairy Cows in HighForage Systems, Anim Feed Sci Techn, 3, 168-206.

Dhiman, T.R., Helmink, E.D., McMahon, D.J., Fife, R.L., Pariza, M.W., 1999. Conjugated linoleic acid content of milk and cheese from cows fed extruded oilseeds, J Dairy Sci, 82, 412- 419.

Ferguson, J.D., Galligan, D.T., Thomsen, N., 
1994. Principal descriptors of body condition score in Holstein cows. $J$ Dairy Sci 77:2695-2703.

Ganjkhanlou, M., Rezayazdi, K., Ghorbani, G.R., Dehghan, B.M., Morraveg, H., Yang, W.Z., 2009. Effects of protected fat supplements on production of early lactation Holstein cows, Anim Feed Sci Technol, 154, 276-283.

Garg, M.R., Sherasia, P.L., Bhanderi, B.M., Gulati, S.K., Scott, T.W., 2003. Effect of feeding rumen protected protein on milk production in lactating buffaloes, Anim Nutr Feed Technol, 3, 151-157.

Garnsworthy, P.C., Masson, L.L., Lock, A.L., Mottram, T.T., 2006. Variation of Milk Citrate with Stage of Lactation and De Novo Fatty Acid Synthesis in Dairy Cows, J Dairy Sci, 5, 1604-1612.

Giger-Reverdin, S., Bezault, N., Sauvant, D., Bertin, G., 1996. Effects of a probiotic yeast in lactating ruminants: Interaction with dietary nitrogen level, Anim Feed Sci Technol, 63, 149-162.

Gulati, S.K., Garg, M.R., Serashia, P.L., Scott, T.W., 2003. Enhancing milk quality and yield in the dairy cow and buffalo by feeding protected nutrient supplements, Asia Pac J Clin Nutr, 12, S61-S63.

Harrison, G.A., Hemken, R.W., Dawson, K.A., Harmon, R.J., Barker, K.B., 1998. Influence of addition of yeast culture supplement to diets of lactating cows on ruminal fermentation and microbial populations, J Dairy Sci, 71, 29672975.

Henics, Z., Combos, S., 1992. Effects of yeast culture on milk production, feed digestibility and ruminal fermentation of dairy cattle. (In Biotechnology in the Feed Industry Volume 8. Alltech Technical Publication, Nicholasville, KY).

Jensen, R.G., 2002. The Composition of Bovine Milk Lipids: January 1995 to
December 2000, J Dairy Sci, 85, 295350.

Kellems, R.O., Lagerstedt, A., Wallentine, M.V., 1990. Effect of feeding Aspergillus oryzae fermentation extract or Aspergillus oryzae plus yeast culture plus mineral and vitamin supplement on performance of Holstein cows during a complete lactation, J Dairy Sci, 73, 2922-2928.

Kelly, 1998. Effect of Intake of Pasture on Concentrations of Conjugated Linoleic Acid in Milk of Lactating Cows, $J$ Dairy Sci, 81, 1630-1636.

Kennelly, J.J., 1996. The fatty acid composition of milk fat as influenced by feeding oilseeds. Anim Feed Sci Technol, 60, 137-152.

Lohrenz, A.K., Duske, K., Schneider, F., Nürnberg, K., Losand, B., Seyfert, H.M., Metges, C.C., Hammon, H.M., 2010. Milk performance and glucose metabolism in dairy cows fed rumenprotected fat during mid-lactation, $J$ Dairy Sci, 93, 5867-5876.

Moallem, U., Lehrer, H., Livshitz, L., Zachut, M., Yakoby, S., 2012. The effects of live yeast supplementation to dairy cows during the hot season on production, feed efficiency, and digestibility, J Dairy Sci, 92, 343-351.

Naik, P.K., Saijpaul, S., Sirohi, A.S., Raquib, M., 2009. Lactation response of cross bred dairy cows fed indigenously prepared rumen protected fat - A field trial, Indian J. of Anim.Sci,79, 10451049.

Nordoy, A., Marchioli, R., Arnesen, H., Videbaek, J., 2001. n-3 Polyunsaturated fatty acids and cardiovascular health, Lipids 36 (2001) S127-S129.

Parnerkar, S., Kumar, D., Shankhpal, S.S., Thube, Marshala, 2011. Effect of feeding bypass fat to lactating buffaloes during early lactation. In: (Proceedings of 14th Biennial Conference of Animal 
Nutrition Society of India 'Livestock Productivity Enhancement with Available FeedResources', Nov. 3-5, Pantnagar, India, pp. 111-112).

Putnam, D.E., Schwab, C.G., Socha, M.T., Whitestone, N.L., Kierstead, N.A., Gaithwaite, B.D., 1997. Effect of yeast culture in the diets of early lactation dairy cows on ruminal fermentation and passage of nitrogen fractions and amino acids to the small intestine, J Dairy Sci, 80, 374-384.

Rajesh, G., Magendra Singh, Roy, A.K., Sukhjinderjit, S., 2014. Effect of prilled fat supplementation on milk yield, composition and plasma hormones in early lactation crossbred cows, J Bio Innov, 3, 216-224.

Reist, M., Erdin, D., Von Euw, D., Tscuemperlin, K., Leuenberger, H., Chilliard, Y., Hammon, H.M., Morel, C., Phlipona, C., Zbinden, Y., Kuenzi, N., Blum, J.W., 2002. Estimation of energy balance at the individual and herd level using blood and milk traits in high-yielding dairy cows, J Dairy Sci, 85, 3314-3327.

Remppis, S., Steingass, H., Gruber, L., Schenkel, H., 2011. Effects of energy intake on performance, mobilization and retention of body tissue, and metabolic parameters in dairy cows with special regard to effects of prepartum nutrition on lactation: a review, Asian-Aust J Anim Sci, 24, 540-572.

Robinson, P.H., Garret, J.E., 1999. Effect of yeast culture (Saccaromyces cerevisiae) on adaptation of cows to postpartum diets and on lactatational performance, $J$ Anim Sci, 77, 988-999.

Sampelayo, M.R.S., Martín Alonso, J.J., Pérez, L., Gil Extremera, F., Boza, J., 2004. Dietary supplements for lactating goats by polyunsaturated fatty acid-rich protected fat. Effects after supplement withdrawal. J Dairy Sci, 87, 1796-
1802.

Schingoethe, D.J., Linke, K.N., Kalscheur, K.F., Hippen, A.R., Rennich, D.R., Yoon, I., 2004. Feed efficiency of midlactation dairy cows fed yeast culture during summer, J Dairy Sci 87, 41784181.

Shabab Khan, Mahendra Singh, Mehla, R.K., Sunita Thakur, Meena, B.S., 2016. Plasma hormones and milk production performances in early lactation buffaloes Supplemented with a mixture of prilled fat, sweetener and toxin binder, Biotech Anim Husb, 32 (1), 1526.

Shelke, S.K., Thakur, S.S., Amrutkar, S.A., 2012. Effect of feeding protected fat and proteins on milk production, composition and nutrient utilization in Murrah buffaloes (Bubalus bubalis), Anim Feed Sci Techn, 171, 98- 107

Shikha, S., Singh, M., Roy, A.K., Thakur, S., 2016. Effect of pre-partum prilled fat supplementation on feed intake, energy balance and milk production in Murrah buffaloes, Vet World, 9.3, 256-259

Sjaunja, L.O., Baevre, L., Junkkarinen, L., Pedersen, J., Setälä, J., 1990. A Nordic proposal for an energy corrected milk (ECM) formula, (In: 27th Session International Committee of Recording and Productivity of Milk Animal, Paris, France, pp. 156-157).

Soder, K.J., Holden, L.A., 1999. Dry matter intake and milk yield and composition of cows fed yeast prepartum and postpartum, J Dairy Sci, 82, 605-610.

Solomon, R., Chase, L.E., Ben-Ghedalia, D., 2000. Bauman, D.E., The effect of nonstructural carbohydrate and addition of full fat extruded soybeans on the concentration of conjugated linoleic acid in the milk fat of dairy cows. $J$ Dairy Sci, 83, 1322-1329.

Sretenovic, L.J., Petrovic, M.P., Aleksic, S., Pantelic, V., Katic, V., Bogdanovic, V., 
Beskorovajni, R., 2008. Influence of yeast, probiotics and enzymes in rations on dairy cows performances during transition, Biotechnol Anim Husb, 24, 33-43.

Srinivas Kumar, D., Rama Prasad, J., Raghava Rao, E., 2011. Effect of supplementation of yeast culture in the diet on milk yield and composition in graded murrah buffaloes. Buff Bullet, 30, 1796-1802.

Staples, C.R., Cullens, F.M., 2005. Implications of fat-feeding practices for lactating dairy cows - effects on milk fat, Adv Dairy Technol, 17, 277-295.

Stein, D.R., Allen, D.T., Perry, E.B., Bruner, J.C., Gates, K.W., Renberger, T.G., Mertz, K., Jones, D., Spicer, L.J., 2006. Effects of feeding propionibacteria to dairy cows on milk yield, milk components, and reproduction, J Dairy Sci, 89, 111-125.

Stella, A.V., Paratte, R., Valnegri, L., Cigalino, G., Soncini, G., Chevaux, E., Dell'Orto, V., Savoini, G., 2007. Effect of administration of live Saccharomyces cerevisiae on milk production, milk composition, blood metabolites and faecal flora in early lactating dairy goats, Small Rumin Res, 67, 7-13.

Swartz, D.L., Muller, L.D., Rogers, G.W., Varga, G.A., 1994. Effects of yeast cultures on performance of lactating dairy cows: A field study, J Dairy Sci,
77, 3073-3080.

Tyagi, N., Thakur, S.S., Shelke, S.K., 2010. Effect of bypass fat supplementation on productive and reproductive performance in crossbred cows. Trop Anim Health Prod, 42, 1749-1755.

Van Soest, P.J., Robertson, J.B., Lewis, B.A., 1991. Methods for dietary fiber, neutral detergent fiber, and nonstarch polysaccharides in relation to animal nutrition, J Dairy Sci, 74, 3583-3597.

White, C.L., Staines, M.H., Phillips, N., Young, P., Coupar, F., Ashes, J.R., Gulati, S.K., 2004. Protected canola meal increase milk protein concentration in dairy cows fed a silagebased diet. Aust J Exp Agric, 44, 827832.

Williams, C.M., 2000. Dietary fatty acids and human health, Ann Zootech, 49, 165180.

Williams, P.E., Tait, C.A., Innes, G.M., Newbold, C.J., 1991. Effects of the inclusion of yeast culture (Saccharomyces cerevisiae plus growth medium) in the diet of dairy cows on milk yield and forage degradation and fermentation patterns in the rumen of steers, J Animal Sci, 69, 3016-26.

Yadav, G., Roy, A.K., Singh, M., 2015. Effect of prilled fat supplementation on milk production performance of crossbred cows, Indian J Anim Nutri, 32, 133-138.

\section{How to cite this article:}

Ajithakumar, H.M., Mahendra Singh, Shikha Sharma, Meeti Punitha, Sikandar Sabab Khan and Brijesh Patel. 2017. Effect of Prilled Fat and Yeast Supplementation on Milk Production, Fatty Acid Profile and Economics of Feeding in Murrah Buffaloes (Bubalus bubalis). Int.J.Curr.Microbiol.App.Sci. 6(10): 1757-1767. doi: https://doi.org/10.20546/ijcmas.2017.610.212 